\title{
Nutritional quality and price of regular food versus gluten-free on E-commerce
}

\section{platforms}

Qualidade nutricional e preço de alimentos regulares versus sem glúten em plataformas de Ecommerce

Calidad nutricional y precio de los alimentos regulares frente a los sin gluten en las plataformas de comercio electrónico

Luce Alves da Silva

ORCID: https://orcid.org/0000-0003-4971-4066 State University of Southweast Bahia, Brazil E-mail: luce_as@hotmail.com

Iasnaia Maria de Carvalho Tavares ORCID: https://orcid.org/0000-0002-0478-7977 State University of Southweast Bahia, Brazil E-mail: iasnaiamct@gmail.com

Cristiane Patrícia de Oliveira

ORCID: https://orcid.org/0000-0003-2261-5789

State University of Southweast Bahia, Brazil E-mail: cristianepatricia@uesb.edu.br

Julieta Rangel de Oliveira

ORCID: https://orcid.org/0000-0001-8571-7294 State University of Santa Cruz, Brazil

E-mail: jroliveira@uesc.br

Muhammad Irfan

ORCID: https://orcid.org/0000-0003-2955-4237

University of Sargodha, Pakistan

E-mail: irfan.biotechnologist@gmail.com

Muhammad Bilal

ORCID: https://orcid.org/0000-0001-5388-3183 Huaiyin Institute of Technology, China bilaluaf@hotmail.com

Marcelo Franco

ORCID: https://orcid.org/0000-0002-7827-789X State University of Santa Cruz, Brazil E-mail: mfranco@uesc.br

\begin{abstract}
Celiac disease is a chronic enteropathy and immune-mediated of the small intestine that affects about $1.1 \%$ to $1.7 \%$ of the world population. Presently the effective medical treatment is the restriction of gluten-containing foods. However, economic cost and nutritional quality have negatively influenced the maintenance of a gluten-free diet in several countries by consumers. In Brazil, the scarcity of information on the economic cost and nutritional quality of these products points to the need for incursions on the topic. In order that compile this information, we accomplish a crosssectional study through a comparative analysis between the economic costs and nutritional information of products targeted at consumers with celiac disease available on an e-commerce platform in Brazil. The study revealed that in Brazil, products with gluten have higher energy value, carbohydrate content, total fats, saturated fat, protein and fiber when compared to their gluten-free versions, while these had a higher economic cost. We evidenced the need for the development of new products with ingredients that add nutritional value without encumber the final cost to the consumer with celiac disease.
\end{abstract}

Keywords: Celiac disease; Restrictive diet; Diet therapy; E-commerce.

\section{Resumo}

A doença celíaca é uma enteropatia crônica e imunomediada do intestino delgado que afeta cerca de 1,1\% a 1,7\% da população mundial. Atualmente o tratamento médico eficaz é a restrição de alimentos que contenham glúten. No entanto, o custo econômico e a qualidade nutricional têm influenciado negativamente a manutenção de uma dieta sem glúten por parte dos consumidores em vários países. No Brasil, a escassez de informações sobre o custo econômico e a qualidade nutricional desses produtos aponta para a necessidade de incursões no tema. Para compilar essas 
informações, realizamos um estudo transversal por meio de uma análise comparativa entre os custos econômicos e as informações nutricionais de produtos direcionados a consumidores com doença celíaca disponíveis em uma plataforma de e-commerce no Brasil. O estudo revelou que, no Brasil, os produtos com glúten apresentam maior valor energético, teor de carboidratos, gorduras totais, gordura saturada, proteína e fibra quando comparados às versões sem glúten, enquanto estes apresentam maior custo econômico. Evidenciamos a necessidade do desenvolvimento de novos produtos com ingredientes que agreguem valor nutricional sem onerar o custo final ao consumidor com doença celíaca.

Palavras-chave: Doença celíaca; Dieta restritiva; Dietotarapia; E-commerce.

\section{Resumen}

La enfermedad celíaca es una enteropatía crónica e inmunomediada del intestino delgado que afecta aproximadamente del 1,1\% al 1,7\% de la población mundial. Actualmente el tratamiento médico eficaz es la restricción de alimentos que contienen gluten. Sin embargo, el costo económico y la calidad nutricional han influido negativamente en el mantenimiento de una dieta libre de gluten por parte de los consumidores en varios países. En Brasil, la escasez de información sobre el costo económico y la calidad nutricional de estos productos apunta a la necesidad de incursiones en el tema. Para recopilar esta información, realizamos un estudio transversal a través de un análisis comparativo entre los costos económicos y la información nutricional de productos dirigidos a consumidores con enfermedad celíaca disponibles en una plataforma de comercio electrónico en Brasil. El estudio reveló que en Brasil, los productos con gluten tienen mayor valor energético, contenido de carbohidratos, grasas totales, grasas saturadas, proteínas y fibra en comparación con sus versiones sin gluten, mientras que estos tenían un mayor costo económico. Evidenciamos la necesidad del desarrollo de nuevos productos con ingredientes que agreguen valor nutricional sin sobrecargar el costo final para el consumidor celíaco.

Palabras clave: Enfermedad celíaca; Dieta restrictiva; Dietoterapia; Comercio electrónico.

\section{Introduction}

Celiac disease (CD) is a chronic enteropathy and immune-mediated of the small intestine that affects people with a genetic predisposition (Melini \& Melini, 2019). CD is characterized by inflammation in the small intestine and villi atrophy (Ashtari et al., 2021), causing different symptoms like, such as malabsorption, chronic diarrhea, weight loss and growth deficiency, to non-classic symptoms such as iron deficiency, bloating, constipation, chronic fatigue, headache, abdominal pain and osteoporosis (Lebwohl, Sanders \& Green, 2018).

The CD interferes in the quality of life of individuals (Pratesi et al., 2018) and is associated with the risk of mortality, through the development of colorectal cancer, osteoporosis, cardiovascular disease, lung disease, and increased malignancy for adenocarcinoma of esophagus, small intestine, colon, liver, and pancreas (Lebwohl, Sanders \& Green, 2018).

Previously CD was regarded as an uncommon disease and limited to children or individuals of European ancestry, however, today $\mathrm{CD}$ is a public health problem, afflicting about of $0.7 \%$ of the world population, this variation depends on the regions: South America (0.4\%), Africa and North America (0.5\%), in Asia (0.6\%) and Europe and Oceania (0.8\%) (Singh et al, 2017). In Brazil, although there are no studies demonstrating prevalence at the national level, a study that assessed the prevalence of people with $\mathrm{CD}$ in a micro-region in the state of Minas Gerais and found a 1.6\% for every 100,000 habitants (Tolentino Júnior, Oliveira \& Assis, 2019).

Despite significant advances in understanding the pathophysiology of $\mathrm{CD}$, the only available treatment for $\mathrm{CD}$ consists of lifelong exclusion of gluten from the diet (Pratesi et al., 2018). Gluten is a protein complex present in some foods, for example gliadins in wheat, secalins in rye and hordeins in barley (Guennouni, El Khoudri, Bourrhouat \& Hilali et al., 2020). The gluten-free diet consists of naturally gluten-free foods, such as fruits, vegetables, milk, and meats (Afonso, Jorge, and Moreira, 2016) and wheat-based food substitutes produced without gluten, such as pasta, cookies, breads, and bakery products (Melini \& Melini, 2019; Babio, et al., 2020).

Maintaining a gluten-free diet is complex due to aspects such as the relationship between food availability and its economic cost, which on average are 22 to 334\% higher when compared to its gluten-containing versions (Panagiotou \& Kontogianni, 2017). In addition, the nutritional quality is bottom, in the amount of protein (Guennouni et al., 2020a) and 
elevated glycemic index (Romão et al., 2020; Trevisan, Pasini \& Simonato, 2019).

Although the availability of gluten-free products has increased in recent years, through supermarkets, specialty stores and/or e-commerce platforms, their economic cost remains elevated (Melini \& Melini, 2019). E-commerce is essential in the global retail sector. E-commerce has presenting an increase in recent years totaling US \$ 29 trillion in volume of e-commerce as a whole in 2017, with estimates of a global increasing of $23 \%$ by 2023 (Haji, 2021), increasing sustained by the increased use of mobile technologies and an expansion of business models (Hillen \& Fedoseeva, 2021). Food sector sales on ecommerce platforms stands out in differents countries (Hillen \& Fedoseeva, 2021). The factors that increase sales in the ecommerce are agility, practicality (Aparicio, Costa \& Moisés, 2021), convenience efficient delivery methods (Tokar, Jensen \& Williams, 2021; Premebida, 2021) and similar retail prices (Hillen \& Fedoseeva, 2021).

The study in Portugal was compared economic cost of products gluten-free versus regular food, through e-commerce platforms and observed that in all categories analyzed, gluten-free products had a higher economic costs than versions containing gluten (Afonso, Jorge \& Moreira, 2016), and in the United Kingdom, a study compared the nutritional quality and economic cost of gluten-free versus regular food products using e-commerce, and observed that gluten-free products were, on average, more expensive (159\%), to products that contain gluten, and high levels of fat, saturated fat, sugar and salt content, and a higher of fiber and protein content (Fry, Madden \& Fallaize, 2018). This lack of information between the economic cost and nutritional quality of gluten-free versus regular food products using e-commerce platforms in Brazil, the present study objective is to fill that gap in the literature.

\section{Methodology}

In order to carry out scientific research, a quantitative study was developed, as defined by Pereira et al., (2018), through the collection of data on e-commerce platforms for online food sales, during the month of February 2021. First, a search performed did to identify websites of supermarkets and online stores selling products through the Google search engine (www.google.com), configured to display results from Brazil in the Portuguese language. The terms used in this search were: "gluten-free products", "supermarkets gluten-free products", "website for online sale of gluten-free products", "purchase of gluten-free products", "online supermarket", "breads for sale online" and "Breads price nutritional information", according to adapted methodology proposed by Guennouni et al., (2020a).

After analyzed the online food sale websites, we use the method adapted by Allen \& Orfila (2018): firstly, product names were typed into the search bar on online food sales websites (for example, bread or cookies or pasta or mixes); secondly, selected product categories as defined by the websites (for example, bakery).

The data collected for each product were: economic cost (converted into euros) and net weight of the product (in grams) and nutritional information: portion (g), energy value (kcal), carbohydrate (g), protein (g), fats total (g), saturated fat (g), trans fat (g), cholesterol (mg), fiber (g) and sodium (mg). Websites that did not present at least one of these of information were disregarded. For purposes of comparison, or customization, the nutritional information did adjusted for $100 \mathrm{~g}$ of each product.

The products were categorize into four product groups depending on the presence of gluten: baking mix (cake mix, bread mix, pie mix, puree mix and dessert mix), bread and bakery products (bread in all its forms, toast and panettone), pasta and cereal products (pasta in various forms, lasagna pasta, breakfast cereals) and cookies and cakes (cookies, filled or not, and cakes in various formats and ready for consumption). According to methodology proposed by Guennouni et al., (2020a), and the minimum number of 10 products for category did applied.

We was realization the conversion of the national currency (1 Real to 6.82 Euro) according to the quotation of by the Central Bank of Brazil, on March 29, 2021, in order to world comparison. 
All results obtained from was analyzed with the SPSS for Windows software (version 13.0; SPSS Inc., Chicago, IL, USA) which enabled the determination of mean, error and standard deviation, median, maximum and minimum values of each nutrient and economic cost of products.

\section{Results and Discussion}

The study resulted in the information on 161 products (Table 1). Although there was, more availability of products containing gluten on the websites consulted, for the present study decided to use a similar number of products in gluten-free versus regular food.

Table 1: Distribution of products by category.

\begin{tabular}{lcc}
\hline & Gluten-free products & Regular food products \\
\hline Breads and bakery products & 20 & 20 \\
Cookies and cakes & 21 & 20 \\
Pasta and cereal products & 23 & 20 \\
Baking mix & 17 & 20 \\
TOTAL & 81 & 80 \\
\hline
\end{tabular}

Source: Authors (2021).

E-commerce is a device that allows the buying and selling of products, the exchange of information and relationships between companies and consumers, and the realization of transactions and payments in internet. Meanwhile in the food sector, only a small fraction of the total food sales is realization by this commerce (Elghannam \& Mesías, 2018), highlighting that in gluten-free food commerce, should be into consideration the low availability of the products, in these commercial platforms, when compared to gluten-containing versions (Allen \& Orfila, 2018).

\subsection{Nutritional Factors}

Table 2 presents the average values, standard error and deviation, median and difference in percentages of the nutritional composition of the analyzed categories. 
Table 2: Nutritional information of the evaluated products.

\begin{tabular}{|c|c|c|c|c|c|}
\hline & & $\begin{array}{c}\text { Breads and bakery } \\
\text { products }\end{array}$ & $\begin{array}{c}\text { Cookies and } \\
\text { cakes }\end{array}$ & $\begin{array}{c}\text { Pasta and cereal } \\
\text { products }\end{array}$ & Baking mix \\
\hline Category & Product type & $\begin{array}{c}\text { Average }^{\mathrm{a}} \\
\text { (standard error) }\end{array}$ & $\begin{array}{c}\text { Average }^{\mathrm{a}} \\
\text { (standard error) }\end{array}$ & $\begin{array}{c}\text { Average }^{\mathrm{a}} \\
\text { (standard error) }\end{array}$ & $\begin{array}{l}\text { Average }^{\mathrm{a}} \\
\text { (standard error) }\end{array}$ \\
\hline \multirow{3}{*}{$\begin{array}{l}\text { Energetic value } \\
\text { (Kcal) }\end{array}$} & GF & $312,30(17,79)$ & $464,92(10,34)$ & $354,44(10,59)$ & $365,35(9,06)$ \\
\hline & RF & $229,69(10,25)$ & $396,62(13,41)$ & $335,43(16,72)$ & $337,55(10,46)$ \\
\hline & Difference (\%) & $35,96 \%$ & $17,22 \%$ & $5,67 \%$ & $8,23 \%$ \\
\hline \multirow[t]{3}{*}{ Carbohydrates (g) } & GF & $49,85(1,63)$ & $62,35(1,71)$ & $72,44(1,89)$ & $76,25(1,27)$ \\
\hline & $\mathrm{RF}$ & $43,81(2,01)$ & $55,10(4,40)$ & $73,06(3,83)$ & $74,94(2,80)$ \\
\hline & Difference $(\%)$ & $13,78 \%$ & $13,16 \%$ & $-0,84 \%$ & $1,75 \%$ \\
\hline \multirow[t]{3}{*}{ Protein(g) } & GF & $8,72(0,48)$ & $6,80(0,53)$ & $8,89(0,53)$ & $5,08(0,74)$ \\
\hline & $\mathrm{RF}$ & $2,98(0,37)$ & $4,48(0,97)$ & $6,16(0,46)$ & $3,74(0,39)$ \\
\hline & Difference $(\%)$ & $192,62 \%$ & $51,78 \%$ & $44,32 \%$ & $35,83 \%$ \\
\hline \multirow[t]{3}{*}{ Total fat (g) } & GF & $7,20(1,04)$ & $19,39(1,58)$ & $3,12(0,83)$ & $4,37(1,03)$ \\
\hline & $\mathrm{RF}$ & $3.56(0,48)$ & $15,89(1,64)$ & $1,30(0,37)$ & $3,94(0,78)$ \\
\hline & Difference $(\%)$ & $102,25 \%$ & $22,02 \%$ & $140,00 \%$ & $10,91 \%$ \\
\hline \multirow[t]{3}{*}{ Saturated fat (g) } & GF & $2,35(0,47)$ & $8,64(1,19)$ & $0,69(0,28)$ & $1,28(0,34)$ \\
\hline & RF & $0,52(0,21)$ & $5,68(0,99)$ & $0,28(0,10)$ & $1,43(0,41)$ \\
\hline & Difference $(\%)$ & $351,92 \%$ & $52,11 \%$ & $146,43 \%$ & $-10,49 \%$ \\
\hline \multirow[t]{3}{*}{ Trans fat (g) } & GF & $0,20(0,14)$ & $0,00(--)$ & $0,00(--)$ & $0,71(0,28)$ \\
\hline & $\mathrm{RF}$ & $0,00(--)$ & $0,00(--)$ & $0,00(--)$ & $0,00(--)$ \\
\hline & Difference $(\%)$ & --- & --- & --- & --- \\
\hline \multirow[t]{3}{*}{ Fibers (g) } & GF & $3,07(0,47)$ & $3,88(0,62)$ & $3,80(0,54)$ & $2,28(0,60)$ \\
\hline & RF & $2,75(0,70)$ & $2,00(0,49)$ & $2,82(0,48)$ & $4,95(1,43)$ \\
\hline & Difference $(\%)$ & $11,64 \%$ & $94,00 \%$ & $34,75 \%$ & $-53,94 \%$ \\
\hline \multirow[t]{3}{*}{ Sodium (mg) } & GF & $434,38(32,18)$ & $311,20(51,29)$ & $186,65(53,99)$ & $440,73(56,54)$ \\
\hline & $\mathrm{RF}$ & $412,63(30,58)$ & $271,41(37,65)$ & $113,50(43,32)$ & $253,68(45,70)$ \\
\hline & Difference $(\%)$ & $5,27 \%$ & $14,66 \%$ & $64,44 \%$ & $73,73 \%$ \\
\hline \multirow[t]{3}{*}{ Cholesterol (mg) } & GF & $0,00(--)$ & $0,00(--)$ & $0,00(--)$ & $0,00(--)$ \\
\hline & $\mathrm{RF}$ & $0,00(--)$ & $1,94(2,03)$ & $0,00(--)$ & $0,00(--)$ \\
\hline & Difference $(\%)$ & --- & --- & --- & --- \\
\hline
\end{tabular}

Subtitle: ${ }^{a}$ Value/100g products; Gluten-free, GF; Regular food, RF Source: Authors (2021).

The energy value of all food groups with gluten was higher when compared to the gluten-free versions. Their values varied from $5.67 \%$ for the "pasta and cereal products" group to $35.96 \%$ for the "bread and bakery products" group. That result can be related to the higher content of carbohydrates and fats in products with gluten. Lower caloric value is related to the reduced quantity of carbohydrates and fats in gluten-free products, is particularly interesting since consumers associate the consumption of gluten-free products with possible health benefits and weight loss.

Regular food products presented a higher carbohydrate, total fat, saturated fat and sodium content than gluten-free products, except the "pasta and cereal products" categorie, which had the highest carbohydrate content compared to gluten-free products $(0.84 \%)$, and "baking mix", that presented a higher saturated fat content compared to the gluten-free version $(10.49 \%$,$) . The cholesterol and trans fat content of most products were not reported or presented zero.$ 
Products with less fat total or saturated content, sugar and sodium assist in reducing the high rates of obesity, cardiovascular disease, hypertension and diabetes mellitus (Monteiro, Rodrigues, Sichieri \& Pereira, 2020) in Brazil about $60 \%$ of the population has a high intake of foods with an elevated content of fat and sugars (Monteiro, Rodrigues, Sichieri \& Pereira, 2020).

All gluten-free products had a lower protein content compared to their traditional versions, with the difference in values varying from $35.83 \%$ for the "baking mix" category to $192.62 \%$ for the "bread and bakery products" category. Other studies also presented lower protein content in gluten-free products (Guennouni et al., 2020a; Allen \& Orfila, 2018; Madden \& Fallaize, 2018). Some studies also observed this trend and proposes that the reduction in protein content is related to the addition of other ingredients such as gluten-free cereals (Babio et al., 2020), pseudocereals, starch, and hydrocolloids (such as xanthan gum, guar gum, and locust bean gum) resulting in loss of nutritional quality (Guennouni et al., 2020a).

Fiber content of the regular food products was higher when compared to the gluten-free versions, except for the "baking mix" category, which presented a fiber content 53.94\% higher. According to RDC 54/2012 of the National Health Surveillance Agency (Anvisa) to be considered a source of fiber, food must have at least $3.00 \mathrm{~g}$ of fiber for every $100 \mathrm{~g}$ of the product. According to this classification, the only category can be considered, as a source of fiber is "baking mix", because it contains on average $4.95 \mathrm{~g}$ of fiber $/ 100 \mathrm{~g}$ of product. This is particularly interesting since dietary fiber present in vegetable foods has phenolic compounds, non-extractable polyphenols, which are beneficial for the action of the intestinal micro biota, and are associated with several health benefits (Gutierrez-Diaz et al., 2021). The frequent use of vegetable fiber in products like as cake mixes may justify the high fiber content of the gluten-free "'baking mix", category. The incorporation of ingredients of vegetable origin, especially cereals and legumes, is a strategy that has been adopted for the development of gluten-free products, with a view to obtaining greater nutritional value and sensory quality (Silva et al., 2021). According to Fry, Madden \& Fallaize (2017), the addition of fiber to gluten-free products can be progress developed by manufacturers in response to frequent published data on fiber deficiency in gluten-free products in order to improve product texture with the addition of hydrocolloids and inulin.

Although the gluten-free category "breads and bakery products" had a presented fiber content average than the regular food products, according to Table S1, the median was higher (2.80) when compared to the with regular food products (2.17), which demonstrate that most gluten-free products have a higher fiber content.

The data presented reveals a better nutritional quality of the gluten-free products considering to caloric value, carbohydrate, fat, and sodium, for most of the categories analyzed. However, the protein and fiber content of most of the gluten-free products is reduced when compared to the regular food products, the removal of ingredients reduces the protein and fiber content of the food, causing possible risks of nutritional inadequacy to people with celiac disease or who habitually consume. The data from this study point to the need for food industries to develop protein-enriching strategies for gluten-free products. 
Research, Society and Development, v. 10, n. 10, e137101018751, 2021

(CC BY 4.0) | ISSN 2525-3409 | DOI: http://dx.doi.org/10.33448/rsd-v10i10.18751

Table S1: Nutritional information of the evaluated products.

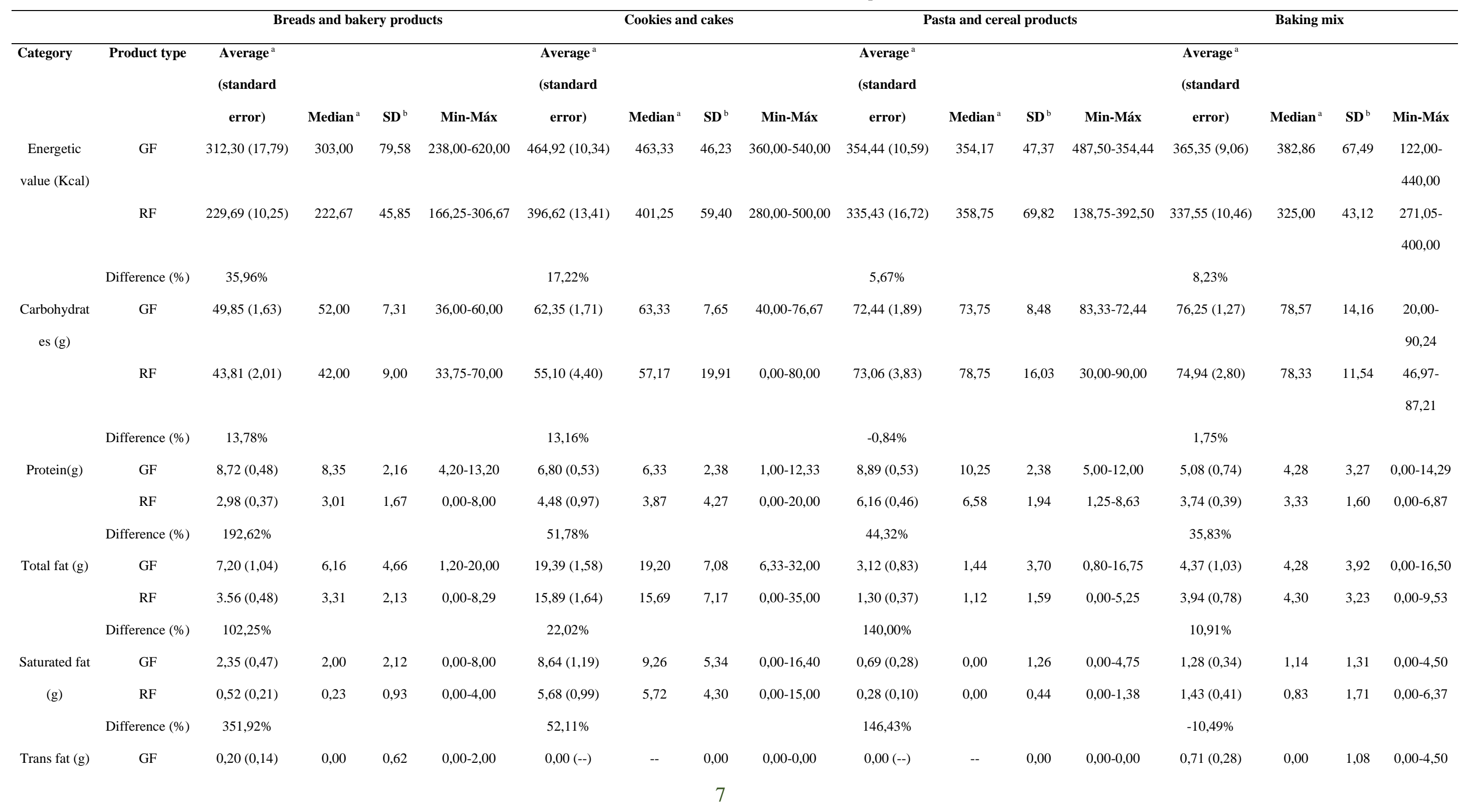


Research, Society and Development, v. 10, n. 10, e137101018751, 2021

(CC BY 4.0) | ISSN 2525-3409 | DOI: http://dx.doi.org/10.33448/rsd-v10i10.18751

\begin{tabular}{|c|c|c|c|c|c|c|c|c|c|c|c|c|c|c|c|c|c|}
\hline & $\mathrm{RF}$ & 0,00 & -- & 0,00 & $0,00-0,00$ & $0,00(--)$ & -- & 0,00 & $0,00-0,00$ & $0,00(--)$ & -- & 0,00 & $0,00-0,00$ & $0,00(--)$ & -- & 0,00 & $0,00-0,00$ \\
\hline & & $(--)$ & & & & & & & & & & & & & & & \\
\hline & Difference $(\%)$ & -- & & & & -- & & & & -- & & & & -- & & & \\
\hline \multirow[t]{3}{*}{ Fibers (g) } & GF & $3,07(0,47)$ & 2,17 & 2,09 & $1,40-9,60$ & $3,88(0,62)$ & 2,83 & 2,78 & $0,00-9,67$ & $3,80(0,54)$ & 2,74 & 2.43 & $9,00-3,79$ & $2,28(0,60)$ & 1,89 & 2,62 & $0,00-9,25$ \\
\hline & $\mathrm{RF}$ & $2,75(0,70)$ & 2,80 & 3,12 & $0,00-10,40$ & $2,00(0,49)$ & 1,62 & 2,12 & $0,00-7,00$ & $2,82(0,48)$ & 2,33 & 2,07 & $0,00-7,25$ & $4,95(1,43)$ & 3,37 & 5,89 & $0,00-22,17$ \\
\hline & Difference (\%) & $11,64 \%$ & & & & $94,00 \%$ & & & & $34,75 \%$ & & & & $-53,94 \%$ & & & \\
\hline \multirow[t]{5}{*}{ Sodium (mg) } & GF & $434,38(32,18)$ & 431,00 & 143,9 & $151,67-712,00$ & $311,20(51,29)$ & 233,33 & 229,3 & $0,00-907,41$ & $186,65(53,99)$ & 25,00 & 241,48 & $0,00-769,70$ & $440,73(56,54)$ & 415,15 & 248,27 & $23,00-$ \\
\hline & & & & 0 & & & & 6 & & & & & & & & & 1005,00 \\
\hline & $\mathrm{RF}$ & $412,63(30,58)$ & 393,33 & 136,7 & $174,00-734,00$ & $271,41(37,65)$ & 235,88 & 218,3 & $26,20-900,00$ & $113,50(43,32)$ & 29,37 & 183,66 & $0,00-700,00$ & $253,68(45,70)$ & 252,17 & 188,45 & $0,00-$ \\
\hline & & & & 8 & & & & 5 & & & & & & & & & 600,00 \\
\hline & Difference $(\%)$ & $5,27 \%$ & & & & $14,66 \%$ & & & & $64,44 \%$ & & & & $73,73 \%$ & & & \\
\hline \multirow{5}{*}{$\begin{array}{c}\text { Cholesterol } \\
\text { (mg) }\end{array}$} & GF & 0,00 & -- & 0,00 & $0,00-0,00$ & $0,00(--)$ & -- & 0,00 & $0,00-0,00$ & $0,00(--)$ & -- & 0,00 & $0,00-0,00$ & $0,00(--)$ & -- & 0,00 & $0,00-0,00$ \\
\hline & & $(--)$ & & & & & & & & & & & & & & & \\
\hline & $\mathrm{RF}$ & 0,00 & -- & 0,00 & $0,00-0,00$ & $1,94(2,03)$ & 0,00 & 8,88 & $0,00-40,70$ & $0,00(--)$ & -- & 0,00 & $0,00-0,00$ & $0,00(--)$ & -- & 0,00 & $0,00-0,00$ \\
\hline & & $(--)$ & & & & & & & & & & & & & & & \\
\hline & Difference (\%) & -- & & & & -- & & & & -- & & & & -- & & & \\
\hline
\end{tabular}

Subtitle: ${ }^{a}$ Value/100g products; ${ }^{\mathrm{b}}$ standard deviation; Gluten-free, GF; Regular food, RF. 
Research, Society and Development, v. 10, n. 10, e137101018751, 2021

(CC BY 4.0) | ISSN 2525-3409 | DOI: http://dx.doi.org/10.33448/rsd-v10i10.18751

\subsection{Economic costs}

Table 3 presents the prices in euros (standard error, and the percentage difference) of regular food and gluten-free of the food groups analyze. Although e-commerce offers larger accessibility to gluten-free foods, the prices of foods is expensive when compared to the commercial establishments (supermarket). (Hopkins \& Soon, 2019; Guennouni, El Khoudri, Bourrhouat \& Hilali, 2020b).

Table 3: Average market economic costs of gluten-free and regular food products (in euros).

\begin{tabular}{lc}
\hline Categories Product & $\begin{array}{c}\text { Average } \\
\text { (Standard error) }\end{array}$ \\
\hline Breads and bakery products & $0,42(0,05)$ \\
Breads and bakery products $\mathrm{GF}^{\mathrm{b}}$ & $0,88(0,12)$ \\
Difference (\%) & $109,52 \%$ \\
Cookies and cakes & $0,83(0,14)$ \\
Cookies and cakes $\mathrm{GF}^{\mathrm{b}}$ & $1,75(0,16)$ \\
Difference (\%) & $110,84 \%$ \\
Pasta and Cereals & $0,38(0,07)$ \\
Pasta and Cereals GF & $0,80(0,06)$ \\
Difference $(\%)$ & $110,52 \%$ \\
Baking mix & $0,41(0,08)$ \\
Baking mix GF & $0,57(0,05)$ \\
Difference $(\%)$ & $39,02 \%$ \\
\hline
\end{tabular}

Subtitle: ${ }^{a}$ Amounts in euros/100g of products; ${ }^{b}$ Gluten-free (GF). Source: Authors, (2021).

According to the data in Table 3, we observed that all the gluten-free products presented higher prices when compared to regular food with the smallest difference being (39.02\%) in the "baking mix" category and the largest difference being $(110,84 \%)$ in the category "Cookies and Cakes". This increase in price can be explained by the use of ingredients such cereals, corn and rice, which have higher economic costs compared to wheat (Babio et al., 2020).

The results of the present study are in agreement with other studies previously reported, as described in Table 4 . 
Research, Society and Development, v. 10, n. 10, e137101018751, 2021

(CC BY 4.0) | ISSN 2525-3409 | DOI: http://dx.doi.org/10.33448/rsd-v10i10.18751

Table 4: Comparison of economic costs (euros) between regular food and gluten-free producers (€).

\begin{tabular}{lcccc}
\hline Product Categories & Our work & Portugal & Greece & United Kingdom \\
\hline Breads and bakery products & 0,42 & 0,52 & $0,30-0,40^{\mathrm{a}}$ & $0,19-0,20^{\mathrm{b}}$ \\
Breads and bakery products GF & 0,88 & 1,56 & $1,25-1,30^{\mathrm{a}}$ & $0,83-0,90^{\mathrm{b}}$ \\
Cookies and cakes & 0,83 & 0,87 & $0,72-0,81^{\mathrm{c}}$ & $0,80-0,84$ \\
Cookies and cakes GF & 1,75 & 2,11 & $2,11-2,25^{\mathrm{c}}$ & $1,56-1,59$ \\
Pasta and Cereals & 0,38 & 0,21 & 0,21 & $0,25-0,53^{\mathrm{d}}$ \\
Pasta and Cereals GF & 0,80 & 0,85 & 0,63 & $0,79-0,90^{\mathrm{d}}$ \\
Baking mix & 0,41 & 0,40 & $0,41^{\mathrm{e}}$ & $0,11-0,37^{\mathrm{f}}$ \\
Baking mix GF & 0,57 & 0,66 & $1,60^{\mathrm{e}}$ & $0,93-1,49^{\mathrm{f}}$ \\
\hline & & Afonso, Jorge \& & Panagiotou \& & Fry, Madden \& \\
& & Moreira (2016) & Kontogianni (2017) & Fallaize (2018) \\
\hline
\end{tabular}

Subtitle: ${ }^{a}$ The time interval refers to the categories (white bread and wholemeal bread) considered by the study ; ${ }^{\mathrm{b}}$ The time interval refers to the categories (whole bread and sliced bread) considered by the study; ${ }^{\mathrm{c}}$ The time interval refers to the categories (cookies and crackers) considered by the study; ${ }^{d}$ The time interval considers the difference in economic costs between food in the categories (cereals, white noodles and whole meal noodles); ${ }^{\mathrm{e}}$ The only representative food in this category in the study was the pizza base; ${ }^{\mathrm{f}}$ The time interval considers the difference in economic costs between food in the category (pizza base and mixes).

Source: Authors (2021).

According to Table 4, when comparing the value of the products sold in Brazil, converted into euros, it was observed that Brazil has the economic costs of food products regular food and gluten-free similar to the values in European countries such as Portugal, Greece, and the United Kingdom.

The result from the Family Budget Survey (FBS), from the period 2017 to 2018 in Brazil, presented that the monthly expenditure on food by family corresponds, on average, to 96.51 euros, considering the total family expenditure. Of the total food expenses that can be substituted by gluten-free products, $10.3 \%$ goes to bakery products and $3.6 \%$ to flour and pasta, totaling $13.9 \%$.

We observed in this study that the products categories "Bread and Bakery Products" and "Pasta and Cereals" glutenfree presented a higher price $(109.52 \%$ and $110.52 \%)$ if compared the regular food. This difference in the monthly family spending, on these products in Brazil to $29.11 \%$ (FBS), which corresponds to $28.09 €$, and represents $17.42 \%$ of a minimum wage in Brazil.

Similar study in Portugal, observed that replacing regular food products with gluten-free food products has to an increase of $€ 110.00$ in monthly family expenses, which corresponds to a $12 \%$ increase, considering the minimum wage in Portugal and a family composition of three people (Afonso, Jorge \& Moreira, 2016).

The replacement of the foods that are part of the Brazilian eating habit for their gluten-free versions provides the increase of 14.68 euros in monthly family spending, which corresponds to the increase of $9.10 \%$ in the minimum wage in Brazil, in the year 2021, and a family composition of 3 people.

Comparing the percentage of spending on food in Brazil (14.2\%) with Portugal (13.4\%) and the minimum wage (2021) 161.29 and 665.00 euros, respectively, we observe a high commitment of the Brazilian income in the food item. This study demonstrates the difficulty in maintaining a diet gluten-free diet in Brazil, to the low minimum wage makes it difficult to purchase these products when compared to other countries. 
Research, Society and Development, v. 10, n. 10, e137101018751, 2021

(CC BY 4.0) | ISSN 2525-3409 | DOI: http://dx.doi.org/10.33448/rsd-v10i10.18751

\section{Conclusion}

The research evidenced that in Brazil, the gluten-free products present lower caloric, carbohydrates, fats, proteins, and fibers content, in addition to a higher final price to the consumer when compared to their regular food versions, in all the categories analyzed. The price of a gluten-free diet may compromise the acquisition of gluten-free food by individuals with celiac disease and other gluten-related disorders, which can result in increased risk of developing morbidities and impact on quality of life the Brazilian. Considering that the well-being of people with gluten-related disorders depends on reliable information on food products, e-commerce platforms must display labels information on all food products available for sale.

Due to the prices of the gluten-free product is a decisive factor in the purchase by people with gluten-related disorders, it is necessary to develop studies in the area, aiming at the development of new products that meet the dietary restrictions of the consumer market, with ingredients that add nutritional value without burdening the final cost to the consumer.

\section{Acknowledgments}

The authors would like to thank the Coordination for the Improvement of Higher Education Personnel (CAPES, Brazil), the National Council for Scientific and Technological Development (Productivity in Research Grants 302259/2018-0, CNPq, Brazil), and the Research Support Foundation of the State of Bahia (FAPESB, Brazil) and the State University of Southwest Bahia (UESB) for their financial assistance, the State University of Santa Cruz (UESC)

\section{References}

Afonso, D., Jorge, R., \& Moreira, A. C. (2016). Alimentos com e sem glúten- análise comparativa de preços de mercado. Acta Portuguesa de Nutrição, 04, 1016. http://dx.doi.org/10.21011/apn.2016.0403

Allen, B., \& Orfila, C. (2018). The Availability and Nutritional Adequacy of Gluten-Free Bread and Pasta. Nutrients, 10(10), 1370. https://doi.org/10.3390/nu10101370

Aparicio, M. Costa, C.J., \& Moises, R. (2021). Gamification and reputation: key determinants of e-commerce usage and repurchase intention, Heliyon, 7(3), e06383. https://doi.org/10.1016/j.heliyon.2021.e063

Arslain, K. (2021). Determinants of gluten-free diet adoption among individuals without celiac disease or non-celiac gluten sensitivity. Appetite, $156,104958$. http://doi.org/10.1016/j.appet.2020.104958

Ashraf, A. R., Tek, N. T., Anwar, A., Lapa, L., \& Venkatesh, V. (2021). Perceived values and motivations influencing m-commerce use: A nine-country comparative study, International Journal of Information Management, 59, 102318. https://doi.org/10.1016/j.ijinfomgt.2021.102318

Ashtari, S., Najafimehr, H., Pourhoseingholi, M. A., Rostami, K., Asadzadeh-Aghdaei, H., Rostami-Nejad, M., Tavirani, M. R., Olfatifar, M., Makharia, G., \& Zali, M. R. (2021). Prevalence of celiac disease in low and high risk population in Asia-Pacifc region: a systematic review and meta analysis. Nature, 11(1), 2383. https://doi.org/10.1038/s41598-021-82023-8

Babio, N., Bellette,L., Besora-Moreno, M., Castillejo,G., Guillén, N., Martínez-Cerezo, F., Vilchez, E., Roger, E., Hernández-Alonso, P., \& Salvadó, J.S.(2020). A comparison of the nutritional profile and price of gluten-free products and their gluten-containing counterparts available in the Spanish Market. Nutrición Hospitalaria, 37(4), 814-822. http://dx.doi.org/10.20960/nh.03016

BRASIL. Resolução RDC no 54, de 12 de novembro de 2012. Dispõe sobre o Regulamento Técnico sobre Informação Nutricional Complementar. Diário Oficial da União, [s. 1.], 2012. Retrieved from: http://bvsms.saude.gov.br/bvs/saudelegis/anvisa/2012/rdc0054_12_11_2012.html. Accessed February 15,2021.

Christoph, M. J., Larson, N., Hootman, K. C., Miller, J. M., \& Neumark-Sztainer, D. (2018). Who Values Gluten-Free? Dietary Intake, Behaviors, and Sociodemographic Characteristics of Young Adults Who Value Gluten-Free Food. Journal of the Academy of Nutrition and Dietetics, 118(8), 1389-1398. https://doi.org/10.1016/j.jand.2018.04.007

Elghannam, A., \& Mesías, F. J. (2018). Social networks as a new marketing channel for animal food products: a qualitative study in Spain. Archivos de Zootecnia, 67(258),260-268. https://doi.org/10.21071/ az.v67i258.3662

Estévez, V., Ayala, J., Vespa, C., \& Araya, M. (2016). The gluten-free basic food basket: a problem of availability, cost and nutritional composition. European Journal of Clinical Nutrition, 70(10), 1215-1217. http://doi.org/10.1038/ejcn.2016.139 
Research, Society and Development, v. 10, n. 10, e137101018751, 2021 (CC BY 4.0) | ISSN 2525-3409 | DOI: http://dx.doi.org/10.33448/rsd-v10i10.18751

Fry, L., Madden, A. M., \& Fallaize, R. (2017). An investigation into the nutritional composition and cost of gluten-free versus regular food products in the UK. Journal of Human Nutrition Dietetics, 31, 108-120. https://doi.org/10.1111/jhn.12502

Guennouni, M., El Khoudri, N., Bourrhouat, A., \& Hilali, A. (2020a). Nutritional quality of gluten-free products in Moroccan supermarkets and e-commerce platforms. Cereal Chemistry. 97(5), 912-920. http://doi.org/10.1002/cche.10313

Guennouni, M., El Khoudri, N., Bourrouhouate, A., \& Hilali, A. (2020b). Availability and cost of gluten-free products in moroccan supermarkets and ecommerce platforms. British Food Journal, 122(12), 1-13. http://doi.org/10.1108/BFJ-06-2019-0411

Gutiérrez-Díaz, I., Salazar, N., Pérez-Jiménez, J., de Los Reyes-Gavilán, C. G., Gueimonde, M., \& González, S. (2021). New players in the relationship between diet and microbiota: the role of macromolecular antioxidant polyphenols. European journal of nutrition, 60(3), 1403-1413. https://doi.org/10.1007/s00394-020-02339-5

Haji, k. (2021). E-commerce development in rural and remote areas of BRICS countries, Journal of Integrative Agriculture, 20(4), 979-997, https://doi.org/10.1016/S2095-3119(20)63451-7

Hillen, J., \& Fedoseeva, S. (2021). E-commerce and the end of price rigidity?. Journal of Business Research, 125, 63-73. https://doi.org/10.1016/j.jbusres.2020.11.052

Hopkins, S., \& Soon, J. M. (2019). Nutritional quality, cost and availability of gluten-free food in england. British Food Journal, 121(11), 2867-2882. http://doi.org/10.1108/BFJ-09-2018-0607

INE. Inquérito às Despesas das Famílias 2015/2016. Lisboa: Instituto Nacional de Estatística, I.P; 2017.

Lebwohl, B., Sanders, D. S., \& Green, P. H. R. (2018). Coeliac disease. Lancet, 391, 70-81. http://dx.doi.org/10.1016/S0140-6736(17)31796-8

Melini, V., \& Melini, F. (2019). Gluten-Free Diet: Gaps and Needs for a Healthier Diet. Nutrients, 11, 170. http://doi.org/10.3390/nu11010170

Monteiro, L. S., Rodrigues, P. R. M., Sichieri,R. \& Pereira, R. A.. (2020). Intake of saturated fat, trans fat, and added sugars by the Brazilian population: an indicator to evaluate diet quality. European Journal of Clinical Nutrition, 74(9), 1316-1324. https://doi.org/10.1038/s41430-020-0582-y

Panagiotou, S., \& Kontogianni, M. D. (2017). The economic burden of gluten-free products and gluten-free diet: a cost estimation analysis in Greece. Journal of Human Nutrition and Dietetics, 30(6), 746-752. http://dx.doi.org/10.1111/jhn.12477

Pereira, A. S., Shitsuka, D.M., Parreira, F. J., \& Shitsuka, R. (2018). Metodologia da pesquisa científica. UFSM.

POF- Pesquisa de orçamentos familiares 2017-2018: primeiros resultados. IBGE, Coordenação de Trabalho e Rendimento. IBGE, 2019.69 p. Retrieved from: https://biblioteca.ibge.gov.br/visualizacao/livros/liv101670.pdf.

Pratesi, C. B., Hauser, W., Uenishi,H., Selleski, N., Nakano, E. Y., Gandolfi, L., Pratesi, R., \& Zandonadi, R. P. (2018). Quality of Life of Celiac Patients in Brazil: Questionnaire Translation, Cultural Adaptation and Validation. Nutrients, 10(9), 1167. http://doi.org/10.3390/nu10091167

Premebida, E. A. (2021). E-commerce em 2020, um cenário de oportunidades em meio a pandemia. Research, Society and Development, 10(2), e59210212984. https://doi.org/10.33448/rsd-v10i2.12984

Romão, B., Botelho, R. B. A., Alencar, E. R., Silva, V. S. N., Pacheco, M. T. B., \& Zandonadi, R. P. (2020). Chemical Composition and Glycemic Index of Gluten-Free Bread Commercialized in Brazil. Nutrients, 12(8), 2234. http://doi.org/10.3390/nu12082234

Silva, L. A. da, Tavares, I. M. de C., Melo Neto, B. A. de, Oliveira, C. P. de, \& Franco, M. (2021). Prospecção tecnológica do uso de vegetais no desenvolvimento de alimentos sem glúten. Research, Society and Development, 10(1), e38010111685. https://doi.org/10.33448/rsd-v10i1.11685

Singh, P., Arora, A. Strand, T. A., Leffler, D. A., Catassi, C., Green, P. H., Kelly, C. P., Ahuja,V., \& Makharia,G. K. (2018). Global Prevalence of Celiac Disease: Systematic Review and Meta-analysis. Clinical Gastroenterology and Hepatology, 16, 823-836. http://dx.doi.org/10.1016/j.cgh.2017.06.037

Tokar, T., Jensen, R., \& Williams, B. D. (2021). A guide to the seen costs and unseen benefits of e-commerce, Business Horizons, 64, 1323-332. https://doi.org/10.1016/j.bushor.2021.01.002

Tolentino Júnior, D. S., Oliveira, C. M., \& Assis, E. M. (2019). Population-based Study of 24 Autoimmune Diseases Carried Out in a Brazilian Microregion. Journal of Epidemiology and Global Health, 9, 243-251. https://doi.org/10.2991/jegh.k.190920.001

Trevisan, S., Pasini, G., \& Simonato, B. (2019). An overview of expected glycaemic response of one ingredient commercial gluten free pasta. Food Science and Technology, 109, 13-16. https://doi.org/10.1016/j.lwt.2019.04.013 